122. Granger GA, Williams TW 1968 Lymphocyte cytotoxicity in vitro. Nature 218:1253-1254

123. Gray PW, Aggarwal BB, Benton CV, Bringman TS, Henzel WJ, Jarrett JA Leung DW, Moffat B, Ng P, Svedersky LP, Palladino MA, Nedwin GE 1984 Cloning and expression of cDNA for human lymphotoxin, a lymphokine with tumor necrosis activity. Nature 312:721-724

124. Aggarwal BB, Henzel WJ, Moffat B, Kohr WJ, Harkins RN 1984 Primary structure of human lymphotoxin derived from 1788 lymphoblastoid cel line. J Biol Chem 260:2334-2344

125. Shalaby MR, Pennica D, Palladino MA Jr 1986 An overview of the history and biologic properties of tumor necrosis factors. Springer Semin Immunopathol 9:33-37

126. Beutler B, Cerami A 1986 Cachectin and tumour necrosis factor as two sides of the same biological coin. Nature 320:584-588

127. Beutler B, Milsark IW, Cerami A 1985 Cachectin/tumor necrosis factor: production, distribution, and metabolic fate in vivo. J Immunol 135:39723977.

128. Dayer J-M, Beutler B, Cerami A 1985 Cachectin/tumor necrosis factor stimulates collagenase and PGE2 production by human synovial cells and dermal fibroblasts. J Exp Med 162:2163-2168

129. Garrett IR, Durie BG, Nedwin GE, Gillespie A, Bringman T, Sabatini M,
Bertolini DR, Mundy GR 1987 Production of lymphotoxin, a bone-resorbing cytokine, by cultured human myeloma cells. N Engl J Med 317:526-532

130. Kehrl JH, Alvarez-Mon M, Delsing GA, Fauci AS 1987 Lymphotoxin is an important T cell-derived growth factor for human B cells. Science 238:1 1441146

131. Hofsli $E$, Austgulen $R$, Nissen-Meyer J 1987 Lymphotoxin-induced growth stimulation of diploid human fibroblasts in the presence and absence of gamma interferon. Scand J Immunol 26:585-588

132. Degliantoni G, Murphy M, Kobayashi M, Francis MK, Perussia B, Trinchieri G 1985 Natural killer (NK) cell-derived hematopoietic colony-inhibiting activity and NK cytotoxic factor. Relationship with tumor necrosis factor and synergism with immune interferon. J Exp Med 162:1512-1530

133. Nedwin GE, Svedersky LP, Bringman TS, Palladino MA Jr, Goeddel DV 1985 Effect of interleukin 2, interferon-gamma, and mitogens on the production of tumor necrosis factors alpha and beta. J Immunol 135:24922497

134. Esparza I, Mannel D, Ruppel A, Falk W, Krammer PH 1987 Interferon gamma and lymphotoxin or tumor necrosis factor act synergistically to induce macrophage killing of tumor cells and schistosomula of Schistosoma mansoni. J Exp Med 166:589-594

\title{
Announcements
}

\section{Abstract Deadline}

The American Pediatric Society and the Society for Pediatric Research announce the abstract deadline for the 1989 annual meeting (May 1-5, 1989, Washington Sheraton Hotel, Washington, D.C.) has been set as January $3,1989$.

For further information contact:

SPR-Ms. Debbie Wogenrich; 2650 Yale Blvd., S.E., Suite 104; Albuquerque, NM 87106; (505)764-9099.

APS-Dr. Audrey K. Brown, Department of Pediatrics, SUNY, Health Science Center at Brooklyn, 450 Clarkson Avenue, Box 49, Brooklyn, NY 11203; (718)270-1692.

\section{International Symposium on Pediatric Rheumatology Paris, July 21-22, 1989}

The main topics of this symposium will be: New insights in the physiopathogeny of inflammatory and autoimmune disorders (cytokines, genetics ... .); Synovitis: Characteristics and functions of cells infiltrating the inflammatory joint; General disorders with joint manifestations in childhood; Therapeutics. General and local treatments, surgery ...

Abstracts forms will be available in November 1988. This meeting is organized for the week preceding the International Congress of Pediatrics held in Paris (July 23-28).

For information contact: Docteur Anne-Marie Prieur, Hôpital Necker-Enfants-Malades, 149, rue de Sèvres, 75743-Paris Cedex 15, France. 